\title{
ANALISIS STRUKTUR WACANA DAN KESALAHAN BERBAHASA TEKS ULASAN BUKU FIKSI SISWA SEKOLAH MENENGAH ATAS
}

\author{
Halimah Nina Rahmawati, Budhi Setiawan, Edy Suryanto \\ Universitas Sebelas Maret \\ Email: halimahninar24@gmail.com
}

\begin{abstract}
Abstrak: Penelitian ini bertujuan untuk menjelaskan kesalahan struktur wacana dan kesalahan berbahasa Indonesia teks ulasan buku fiksi siswa kelas XI SMA Muhammadiyah 1 Karanganyar. Penelitian ini mendeskripsikan penyebab kesalahan dan upaya yang dapat dilakukan guru untuk meminimalkan kesalahan selanjutnya. Penelitian ini merupakan studi kasus dengan data penelitian berupa kesalahan struktur wacana dan kesalahan berbahasa dalam teks ulasan buku fiksi karya siswa. Teknik pengumpulan data dilakukan dengan cara observasi, uji kompetensi, dan wawancara. Uji validitas menggunakan triangulasi sumber data dan triangulasi teori. Teknik analisis data menggunakan analisis isi. Hasil penelitian ditemukan: (1) kesalahan struktur wacana, yaitu 20 kesalahan judul teks ulasan, 17 kesalahan penutup, 12 kesalahan isi, dan 11 kesalahan pendahuluan; (2) kesalahan berbahasa meliputi 174 kesalahan huruf besar, 60 kesalahan penulisan tanda baca koma, 36 kesalahan tanda baca titik, 18 kesalahan kata depan, 10 kesalahan huruf miring, 4 kesalahan titik dua, 3 kesalahan tanda hubung, 3 kesalahan kata ulang, 3 kesalahan partikel, 2 kesalahan penulisan titik koma, 95 kesalahan diksi, kalimat, dan paragraf; (3) faktor penyebab kesalahan berbahasa, yaitu tidak adanya materi ejaan dan tanda baca pada silabus, kurangnya motivasi siswa, dan pengaruh bahasa asing serta bahasa daerah; (4) upaya mengurangi kesalahan berbahasa, yaitu pengintegrasian materi, memberikan motivasi kepada siswa, serta meningkatkan penguasaan kaidah kebahasaan yang benar.
\end{abstract}

Kata kunci: kesalahan berbahasa, teks ulasan, buku fiksi

\section{DISCOURSE STRUCTURE AND LANGUAGE ERROR ANALYSIS ON REVIEWS TEXT OF BOOK FICTION IN SENIOR HIGH SCHOOL}

\begin{abstract}
This study aims to explain the errors of discourse structure and mistake in Indonesian language text review fiction book grade XI students of Muhammadiyah 1 Karanganyar High School. This study describes the causes of errors and the efforts teachers can make to minimize further errors. This research is a case study with research data in the form of discourse structure and language errors in the text of fiction book reviews by student. Data collection technique $s$ were carried out by means of observation, competency tests, and interviews. Validity test used triangulation of data source and theory triangulation. Data analysis techniques using content analysis. The result of the study found: (1) discourse structure errors, namely 20 errors in the review text title, 17 closing errors, 12 content errors, and 11 preliminary errors, (2) language errors include 174 uppercase mistakes, 60 comma punctuation errors, 36 dot punctuation errors, 18 preposition errors, 10 italic errors, 4 colon errors, 3 hyphen errors, 3 repeat words errors, 3 particle errors, 2 semicolon errors, 95 errors diction, sentences, and paragraphs; the absence of spelling and punctuation material on the syllabus, lack of student motivation, and the influence of foreign languages and regional languages; (4) efforts to reduce language errors, namely integrating the material, providing motivation to students, and increasing mastery of the correct linguistic rules.
\end{abstract}

Keywords: language errors, review texts, fiction books

$\begin{array}{rlrlr}\text { PENDAHULUAN } & & & \text { bermasyarakat, yaitu sebagai sarana } \\ \text { Keberadaan } & \text { bahasa } & \text { memiliki } & \text { komunikasi antar sesama. Adanya } \\ \text { peranan penting } & \text { dalam } & \text { kehidupan } & \text { perkembangan teknologi menjadikan }\end{array}$

BASASTRA Jurnal Bahasa, Sastra, dan Pengajarannya

Volume 8 Nomor 1, April 2020, P-ISSN 2302-6405, E-ISSN 2714-9765 
informasi beredar dengan mudah dan cepat sehingga diperlukan kemampuan penyampaian pesan yang baik dengan bahasa tulis agar tidak terjadi salah persepsi antar pembaca. Dalam pembelajaran di sekolah, siswa dituntut menguasai empat keterampilan berbahasa, yaitu keterampilan menyimak, berbicara, membaca serta menulis. Keempat keterampilan tersebut memerlukan proses latihan untuk mencapai keterampilan tingkat yang lebih tinggi.

Perkembangan ilmu pengetahuan dan teknologi di zaman modern menjadikan bahasa sebagai suatu kebutuhan. Keterampilan berbahasa masyarakat harus benar dan tepat agar informasi yang disampaikan oleh penutur dapat dipahami dengan baik oleh lawan tutur. Selain bahasa lisan, keberadaan bahasa tulis sangat berpengaruh dalam kehidupan masyarakat dengan arus modernisasi masa kini. Terlebih pesatnya perkembangan informasi berita serta pengetahuan lewat media cetak maupun media elektonik memudahkan siapa saja untuk menulis di media-media yang telah tersedia.

Kenyataannya, kemampuan literasi masyarakat Indonesia masih cukup rendah. Berdasarkan studi "Most Littered Nation In the World" yang dilakukan oleh Central Connecticut State University tahun 2016, Indonesia dinyatakan menduduki peringkat 60 dari 61 negara di dunia mengenai tingkat minat membaca. Rendahnya minat baca secara otomatis mempengaruhi minat menulis masyarakat yang terhitung rendah pula. Dikutip dari perpustakaan.bappenas.go.id, Pakar pendidikan A. Chaedar Alwasilah M.A. $\mathrm{PhD}$., menyatakan masalah terbesar dunia pendidikan bahasa di Indonesia adalah kemampuan dalam bidang kepenulisan yang rendah.

Menurutnya, masalah tersebut terjadi karena pembelajaran menulis di sekolah tidak dilaksanakan dengan benar. Berdasarkan penelitian yang dilakukan, ditemukan banyak kasus hasil karya penulisan siswa di sekolah tidak dibaca, dikoreksi, diberi umpan balik oleh guru, dan juga tidak dikembalikan ke siswa yang bersangkutan. Hal tersebut menjadikan siswa kurang tertarik mencari tahu apakah hasil tulisan mereka tepat atau tidak, padahal ketepatan dalam keterampilan menulis sangat dibutuhkan bagi siswa dalam pembelajaran di sekolah, salah satunya keterampilan dalam menulis teks ulasan.

Di dalam silabus kurikulum 2013 pada Kompetensi Dasar 3.11 terdapat materi yang relevan dengan penelitian yang sedang dikaji yaitu menyusun ulasan dari buku fiksi yang telah dibaca dengan menuliskan keunggulan dan kelemahan dari buku fiksi tersebut. Permasalahan yang timbul dari kegiatan tersebut adalah masih banyak ditemukan struktur teks dan penggunaan bahasa Indonesia yang kurang tepat. Kesalahan tersebut diketahui dari hasil pengamatan dan analisis terhadap teks ulasan buku fiksi yang dibuat oleh siswa.

Berdasarkan penelitian yang dilakukan oleh Novitasari (2015) dengan judul "Kemampuan Menulis Teks Ulasan/Resensi Siswa Kelas VIII SMP Negeri 2 Kotagajah" dapat disimpulkan bahwa tingkat menulis teks ulasan siswa masih tergolong rendah dalam kategori ketepatan penggunaan bahasa dan ejaan. Dari 60 responden hanya terdapat 3 siswa yang memperoleh nilai dengan kategori baik sekali, 10 siswa kategori baik, 23 siswa kategori cukup, 5 siswa kategori kurang, dan 19 siswa kategori kurang sekali.

Observasi yang dilakukan penulis, dapat disimpulkan bahwa pembelajaran menulis siswa dinilai masih rendah. Kesalahan penulisan masih banyak ditemukan, baik dalam masalah isi maupun masalah bahasa yang digunakan. Salah satu penyebab rendahnya kemampuan menulis siswa adalah dikarenakan siswa kurang mengeksplorasi mengenai materi 
pelajaran bahasa Indonesia sehingga pengaplikasian pembelajaran bahasa secara nyata dalam kehidupan sehari-hari juga rendah.

Menulis teks ulasan sangat dibutuhkan untuk membantu pembaca dalam memperoleh informasi mengenai kelebihan dan kekurangan suatu karya, misal: buku, novel, film, dan sebagainya.

Penelitian mengenai teks ulasan pernah dilakukan oleh Siregar (2018) dengan judul "Kemampuan Mengidentifikasi Struktur dan Unsur Kebahasaan oleh Siswa Kelas VIII SMP Negeri 12 Medan Tahun Pelajaran 2017/2018". Penelitian tersebut menganalisis penggunaan struktur dan unsur kebahasaan dalam teks ulasan. Hasil penelitian menyatakan bahwa nilai ratarata kemampuan siswa mengidentifikasi struktur teks ulasan sebesar 79,17, sedangkan rata-rata identifikasi unsur kebahasaan sebesar 44,44 yang masuk kategori rendah.

Kendala siswa yang menyebabkan kurangnya antusias dalam melaksanakan pembelajaran menulis antara lain karena kurangnya referensi dan keterbatasan informasi akibat tingkat membaca buku yang rendah sehingga sulit memulai untuk menulis dan menentukan tema. Gordon (2008) dalam penelitiannya menyimpulkan bahwa untuk memperkaya kosakata dalam menulis, siswa dapat mengandalkan bacaan yang ada dalam buku, jurnal, bahkan situs-situs web. Melalui cara tersebut, siswa dapat menuangkan ide-ide mereka ke dalam sebuah tulisan secara lebih efektif

Kegiatan menulis teks ulasan sesuai dengan observasi yang dilakukan di SMA Muhammadiyah 1 Karanganyar, masih banyak ditemukan kesalahan. Kesalahan tersebut antara lain ditemukan penulisan ejaan maupun tanda baca yang tidak sesuai dengan tata aturan yang berlaku. Penyebabnya adalah siswa cenderung malas sehingga minat baca dan minat dalam mengeksplorasi materi sangat kurang. Penguasaan kaidah bahasa yang kurang dapat menyebabkan siswa secara tidak sadar melakukan kesalahan dalam penulisan. Selain itu, kesulitan menuangkan gagasan disebabkan karena siswa tidak terbiasa mengubah gagasan tersebut ke dalam bentuk tulisan. Hal tersebut relevan dengan apa yang ditemukan peneliti ketika melakukan prapenelitian di sekolah. Faktor-faktor tersebut tentunya harus diperbaiki dan diminimalkan karena dapat menghambat proses belajar mengajar dan juga mempengaruhi hasil akhir pembelajaran.

Berdasarkan latar belakang yang telah diuraikan di atas, penulis bermaksud melakukan penelitian mengenai kesalahan berbahasa yang terdapat dalam teks ulasan karya siswa kelas XI SMA Muhammadiyah 1 Karanganyar. Peneliti ingin mengetahui jenis-jenis kesalahan yang sering dilakukan siswa serta penyebabnya. Hasil dari penelitian ini diharapkan dapat membantu siswa memahami materi pembelajaran, sehingga dapat mengurangi pengulangan kesalahan bahasa yang terjadi.

\section{METODE PENELITIAN}

Metode penelitian yang digunakan dalam penelitian ini adalah deskriptif kualitatif. Hal tersebut sesuai dengan pendapat Bogdan dan Taylor yang mengatakan bahwa penelitian kualitatif menghasilkan data deskriptif berupa katakata tertulis atau lisan dari orang atau perilaku yang dapat diamati secara holistik atau utuh (Moleong, 2007:3). Pendapat lain, menurut Nasution (1988:5) pada penelitian kualitatif perlu dilakukan pengamatan, penginteraksian, serta penafsiran yaitu mengamati orang dalam suatu lingkungan yang akan diteliti, berinteraksi dengan mereka, serta memahami bahasa dan tafsiran mereka tentang apa yang sedang diteliti sehingga peneliti butuh turun langsung ke lapangan untuk menggali data-data. 
Data dalam penelitian ini merupakan data kualitatif. Data kualitatif yang digunakan adalah dokumen dan informan. Dokumen pada penelitian ini adalah teks ulasan buku fiksi siswa. Data yang diperoleh peneliti adalah 24 data, tetapi terdapat 21 data yang di analisis sesuai dengan kriteria, sedangkan informan dalam penelitian ini adalah informasi yang dituturkan oleh guru bahasa Indonesia SMA Muhammadiyah 1 Karanganyar. Teknik yang digunakan dalam penelitian ini adalah purposive sampling, yaitu teknik sampel bertujuan. Alasan pemilihan menggunakan teknik samping ini adalah peneliti memiliki pertimbangan serta tujuan tertentu sehingga diperoleh data dan informasi yang dibutuhkan peneliti.

Teknik pengumpulan data dilakukan dengan cara mengkaji dokumen berupa teks ulasan buku siswa menggunakan teknik analisis isi atau content analysis. Diawali dengan kegiatan observasi yang dilaksanakan sebelum pengambilan data, lalu meminta siswa untuk melakukan uji kompetensi menulis teks ulasan buku. Teks ulasan tersebut dikumpulkan untuk diseleksi sesuai kriteria-kriteria yang telah ditetapkan sebelumnya. Tahap terakhir, peneliti mengkaji dokumen atau arsip berupa teks ulasan tersebut. Dalam penelitian ini, peneliti mengumpulkan data yang bersifat verbal dengan cara melakukan wawancara mendalam atau indeep interview dengan guru dan siswa sehingga peneliti dapat menyimpulkan mengenai faktor-faktor penyebab kesalahan berbahasa siswa serta upaya mengurangi kesalahan tersebut.

Uji validitas data dalam penelitian ini menggunakan teknik triangulasi sumber data dan trianggulasi teori, sedangkan teknik pengambilan sampel menggunakan teknik content analysis atau biasa disebut dengan analisis isi. Teknik analisis isi banyak digunakan untuk menganalisis isi media cetak maupun elektronik. Menurut Eriyanto (2015:10) analisis isi dijelaskan sebagai metode ilmiah untuk mempelajari dan menarik suatu kesimpulan atas fenomena yang diteliti dengan memanfaatkan dokumen berupa teks.

\section{HASIL DAN PEMBAHASAN}

Pada bagian ini menjelaskan mengenai hasil penelitian berdasar permasalahan yang diungkap pada rumusan masalah, yaitu mengenai struktur wacana dan jenis-jenis kesalahan berbahasa teks ulasan buku fiksi siswa kelas XI SMA Muhammadiyah 1 Karanganyar. Penelitian dilakukan dengan mencatat kesalahan kemudian menganalisis kesalahan-kesalahan tersebut. Berdasarkan analisis yang telah dilakukan, ditemukan bahwa semua data yang diteliti memiliki kesalahan. Pada struktur teks ulasan ditemukan kesalahan pada bidangbidang berikut: (1) judul teks ulasan, (2) pendahuluan atau orientasi, (3) tafsiran isi, serta (4) penutup dan simpulan.

Berdasarkan penelitian yang dilakukan, bentuk kesalahan struktur wacana teks ulasan buku fiksi mencakup keseluruhan komponen. Kesalahan paling banyak terdapat pada penulisan judul teks ulasan. Berdasarkan 21 data yang di analisis, ditemukan 20 judul teks ulasan yang kurang sesuai. Kesalahan struktur wacana yang lain ditemukan bahwa dalam data teks ulasan buku fiksi terdapat kesalahan penulisan pendahuluan atau orientasi yang disebabkan karena siswa tidak mencantumkan bagian tersebut. Beberapa siswa langsung menuliskan mengenai sinopsis buku tanpa di awali dengan pendahuluan hal tersebut tidak sesuai dengan pendapat Waridah \& Wahya (2017:291) yang menyatakan bahwa pendahuluan teks ulasan dapat diawali dengan memberikan perbandingan terhadap buku sejenis karya penulis sendiri atau karya penulis lain. Dapat pula diawali dengan memaparkan riwayat kepenulisan pengarang, karya-karya yang pernah di tulis, atau pemaparan keunikan buku.

Menurut Sukardi dan Sutarni (2008:32) struktur teks ulasan mengenai 
tafsiran isi memuat kelebihan dan kekurangan isi buku, penilaian terhadap penggunaan bahasa, dan perwajahan buku seperti ukuran dan jenis kertas, ilustrasi, serta warna sampul buku. Pada penulisan sinopsis buku, siswa mencantumkan sinopsis secara keseluruhan cerita. Hal tersebut merupakan kesalahan karena membuat pembaca merasa tidak tertarik kembali membaca buku karena isi buku sudah dituliskan secara lengkap pada teks ulasan tersebut. Penulisan kelebihan dan kekurangan buku tidak dijabarkan secara kritis dan tidak disertai dengan alasan pemilihan. Pada bagian penutup teks ulasan, beberapa tidak dicantumkan mengenai penegasan ulang isi teks ulasan serta saran perbaikan maupun saran rekomendasi untuk pembaca.

Penelitian ini relevan dengan penelitian yang dilakukan sebelumnya oleh Ariningsih (2012) berjudul "Analisis Kesalahan Berbahasa Indonesia dalam Karangan Eksposisi Siswa Sekolah Menengah Atas" menemukan kesalahan berbahasa karangan siswa dalam bidang ejaan, diksi, kalimat, dan paragraf. Sama halnya dengan hal di atas, penelitian ini memfokuskan kesalahan berbahasa Indonesia ditinjau dalam bidang kesalahan ejaan dan tanda baca, kesalahan diksi, kesalahan kalimat, dan kesalahan paragraf pada teks ulasan buku fiksi siswa.

Berikut ini akan dibahas mengenai kesalahan struktur teks ulasan beserta jenis-jenis kesalahan berbahasa Indonesia teks ulasan siswa kelas XI SMA Muhammadiyah 1 Karanganyar.

\section{Kesalahan Struktur Wacana Judul Teks Ulasan}

Dari 21 data yang dianalisis, terdapat beberapa data mengenai judul teks ulasan yang kurang sesuai, antara lain terdapat judul yang tidak selaras dengan isi teks, siswa menulis judul teks ulasan sama dengan judul buku, ada pula yang tidak menuliskan judul, dan hanya terdapat satu data yang menuliskan judul secara tepat.
Berikut adalah salah satu kesalahan judul teks ulasan yang kurang tepat.

(1) Resensi Novel $5 \mathrm{~cm}$

(2) Resensi Novel "Assalamu'alaikum Beijing"

Judul teks ulasan tersebut kurang tepat, pasalnya data yang ditemukan tidak sesuai dengan syarat-syarat pemilihan judul yang baik menurut Akhadiah (1993: 9-10) yaitu (1) Judul harus sesuai dengan topik pembahasan, (2) sebaiknya ditulis dalam bentuk frase bukan dalam bentuk kalimat, (3) ditulis dalam bentuk sesingkat mungkin agar efektif, (4) harus dinyatakan secara jelas agar tidak menimbulkan ambiguitas bagi para pembaca.

\section{Pendahuluan atau Orientasi}

Kesalahan penulisan pendahuluan atau orientasi teks ulasan buku dapat dilihat pada data dengan buku berjudul "Eva Ustadzah Cinta Ketiban Cinta" berikut.

(3) "Karena sudah 27 kali ditolak saat wawancara kerja, akhirnya Eva memutuskan berwirausaha biro jodoh islami. Agar mendapat citra yang lebih islami dan bergengsi, Eva yang belum secara kafah mengenakan jilbab nekat menyamar menjadi "ustadzah cinta" dengan mengubah seluruh penampilannya." $(3 / 1)$

Analisis teks ulasan buku pada data 3 tersebut tidak tepat. Pada data tersebut tidak dicantumkan bagian pendahuluan atau orientasi sebagai awalan penulisan teks ulasan.

\section{Tafsiran Isi}

Tafsiran isi memuat sinopsis atau ringkasan isi buku, penjelasan isi buku yang dijabarkan bab demi bab, serta kelebihan dan kekurangan suatu buku.

(4) A. IDENTITAS BUKU

$\begin{array}{ll}\text { Judul buku } & : \text { Laskar } \\ \text { Pelangi } & \text { : Roman }\end{array}$


Penerbit

Yogyakarta, Bandung Pustaka ...

\section{B. SINOPSIS}

...

C. KELEBIHAN

...

\section{KEKURANGAN}

Penulisan tafsiran isi seperti pada data di atas kurang tepat, sebab tidak seperti penulisan teks ulasan pada umumnya yang memuat paragraf per paragraf sehingga menjadi wacana yang utuh. Pada teks ulasan tersebut ditulis poin per poin. Padahal dalam penulisan teks ulasan tidak perlu pemisahan bagian per bagian, penulis hanya perlu menuliskan menjadi satu kesatuan wacana.

Penutup

Simpulan berisi penjabaran penegasan ulang isi teks ulasan, sedangkan saran dapat berupa saran perbaikan buku maupun saran rekomendasi buku untuk pembaca.

(5) "Banyak penggunaan diksi yang tidak pas pada novel Nathan ini. Seringkali pembaca menemukan pemilihan diksi yang tidak pas saat membacanya. Pembaca merasa tidak cocok dengan penggunaan saya pada karakter Nathan yang sebenarnya bad guy." (4/5)

Pada paragraf di atas yang terletak pada akhir wacana ditemukan penulisan teks ulasan yang masih membahas mengenai kekurangan buku. Dalam hal itu, kekurangan buku masuk pada bagian tafsiran isi teks ulasan, sehingga dari hal tersebut dapat diketahui teks tersebut tidak memiliki bagian penutup.

\section{Kesalahan Berbahasa Indonesia Kesalahan Ejaan dan Tanda Baca Penulisan Huruf Kapital \\ Pemakaian huruf kapital harus sesuai dengan Pedoman Umum Ejaan}

Bahasa Indonesia (PUEBI). Berikut merupakan data kesalahan penulisan huruf kapital.

(6) Novel “jejak langkah" ini sangat berguna... (10/10)

(7) judul buku : Surat Kecil Untuk Tuhan (17/1)

Data di atas merupakan penulisan huruf kapital yang kurang tepat karena adanya judul yang tidak ditulis menggunakan huruf kapital pada huruf pertamanya. Kesalahan pada tersebut merupakan penulisan judul buku fiksi yang tidak tepat. Judul buku, judul artikel, judul karangan, dan lainnya ditulis menggunakan huruf kapital, kecuali pada kata tugas seperti yang, di, ke, dari, dan, untuk, yang tidak berada pada posisi awal kalimat.

\section{Garis Bawah}

Penulisan Huruf Miring atau

Berikut merupakan kesalahan penggunaan huruf miring pada teks ulasan buku fiksi siswa dalam beberapa data sampel.

(8) ...tidak sesuai dengan kepribadian Nathan yang berkarakter bad guy.

Penulisan kata asing dan nama ilmiah di atas tidak tepat. Seharusnya ditulis menggunakan huruf miring.

Penulisan Tanda Baca Titik (.)

Penggunaan tanda titik dalam penulisan seringkali dihiraukan dan dianggap masalah sepele bagi sebagian orang, terutama bagi kalangan siswa di sekolah. Pemakaian tanda titik memiliki berbagai fungsi dan tujuan, salah satunya sebagai tanda henti yang terletak pada akhir kalimat. Berikut merupakan data kesalahan tanda titik yang terdapat dalam sampel.

(9) Penulisan bahasa yang mudah dipahami oleh pembaca

Data (19/4) merupakan kesalahan yang paling banyak ditemukan, yaitu tidak adanya tanda baca titik pada akhir kalimat berita.

Penulisan Tanda Baca Koma (,) 
Tanda koma memiliki fungsi mendasar sebagai pemisah antara bagian satu dengan bagian lain dalam kalimat, sehingga pembaca dapat memahami dengan tepat kalimat yang dimaksud. Berikut merupakan data kesalahan tanda koma yang terdapat dalam sampel.

(10) _..di Belitung Timur. Desa Gantung Kabupaten Gantong. $(9 / 1)$

Tanda koma digunakan untuk memisahkan alamat yang ditulis berurutan. Penulisan yang benar pada data di atas adalah di Belitung Timur, Desa Gantung, Kabupaten Gantong.

Penulisan Tanda Baca Titik Dua

Pemakaian tanda titik dua umum digunakan pada resensi atau teks ulasan, yaitu pada penulisan bagian identitas suatu buku yang sedang di ulas. Berikut merupakan data kesalahan tanda titik dua.

(11) Judul buku = Laskar Pelangi Penerbit $=$ Yogyakarta,

Bandung Pustaka ... (14/1)

Penggunaan tanda titik dua pada data di atas kurang tepat. Kata atau ungkapan yang diikuti oleh pemerian dipisahkan dengan tanda baca titik dua, bukan tanda sama dengan.

\section{Penulisan Tanda Hubung (-)}

Salah satu fungsi tanda hubung adalah untuk menghubungkan atau merangkai suatu huruf maupun kata. Berikut merupakan data kesalahan tanda hubung yang terdapat dalam sampel.

(12) Hari hari pasca bencana mereka habiskan bersama... $(16 / 2)$

Kesalahan penulisan pada data di atas disebabkan karena tidak adanya tanda hubung untuk menyambung unsur kata ulang. Penulisan unsur kata ulang yang benar pada data tersebut adalah "Hari-hari pasca bencana mereka habiskan bersama...".

Penulisan Kata Depan
Kata depan dalam aturan penulisan bahasa Indonesia terdiri dari di, ke, dan dari. Penulisan kata depan berbeda dengan penulisan awalan. Sesuai dengan pedoman yang berlaku, kata depan ditulis secara terpisah dengan kata yang mengikutinya. Penulisannya dapat digabung jika kata tersebut sudah lazim digunakan sebagai satu kata utuh seperti "kepada" dan "daripada". Berikut merupakan penemuan data kesalahan penulisan kata depan.

(13) ...ditulis oleh Pram semasa dipulau Buru... (10/3)

Penulisan kata depan pada data di atas kurang tepat karena ditulis sambung. Kesalahan paling banyak adalah pada penulisan kata depan di. Siswa belum dapat membedakan antara penulisan kata depan "di" sebagai awalan dan sebagai kata depan. Dari data di atas, penulisan yang benar adalah ditulis secara pisah.

\section{Penulisan Kata Ulang}

Penulisan kata ulang dilengkapi dengan tanda hubung (-) diantara unsurunsurnya. Beberapa siswa yang kurang teliti menulis kata ulang dengan tidak mencantumkan tanda hubung antara unsurunsurnya seperti pada data berikut.

(14) Hari hari pasca bencana mereka habiskan bersama... $(16 / 2)$

Berdasarkan penulisan data di atas, seharusnya penulisan kata ulang diberi tanda hubung menjadi "Hari-hari pasca bencana mereka habiskan bersama..."

\section{Penulisan Partikel}

Partikel "pun" pada penulisan kalimat ditulis secara terpisah dari kata yang mendahuluinya, kecuali pada partikel "pun" yang sudah lazim ditulis serangkai seperti pada kata "bagaimanapun", "adapun", "walaupun", "maupun", dan "sekalipun". Berikut adalah data kesalahan penulisan kata partikel yang ditemukan dalam teks resensi siswa.

(15) Hubungan merekapun berakhir. (13/3)

Penulisan yang benar adalah memenggal partikel "pun" dengan kata 
sebelumnya, sehingga perbaikan dari data tersebut adalah "Hubungan mereka pun berakhir".

\section{Kesalahan Penulisan Diksi}

Pemilihan kata yang kurang tepat dapat menyebabkan salah tafsir antar pembaca. Berikut adalah data kesalahan penulisan diksi yang ditemukan dalam teks resensi siswa.

(16) ...mereka berkumpul untuk menanjak gunung yang sangat fenomenal di Indonesia... (1/3)

Temuan pada data tersebut dapat diketahui bahwa pemilihan kata menanjak kurang tepat diletakkan pada kalimat tersebut. Meskipun kata menanjak dan kata mendaki terdapat kemiripan makna, tetapi keduanya memiliki maksud yang berbeda. Kata mendaki merupakan kata yang menunjukkan aktivitas melakukan suatu hal, sedangkan kata menanjak merupakan adjektiva atau biasa disebut dengan kata sifat, yaitu sering digunakan untuk menunjukkan sifat atau keadaan suatu hal.

\section{Kesalahan Penulisan Kalimat}

Kesalahan penulisan kalimat juga dipengaruhi oleh penggunaan kata-kata yang berlebihan sehingga menjadi tidak ekonomis. Agar menjadi kalimat yang efektif, maka siswa harus memilih katakata secara tepat dan tidak memberikan pengulangan kata yang sama dalam satu kalimat

(17) Pada novel ini tidak dijelaskan secara jelas oleh pengarang gambaran fisik dari tokoh-tokoh yang ada di dalam novel, sehingga sang pembaca harus menerka-nerka bagaimana gambaran tokoh terutama fisik sang tokoh dalam novel. (16/5)

Data tersebut terdapat kesalahan dalam penulisan kalimat, yaitu adanya kemubadziran kata-kata yang digunakan. Penulisan kata tidak dijelaskan secara jelas tergolong tidak ekonomis dan terkesan berlebihan karena terdapat kata dijelaskan dan jelas yang hampir mirip. Kata tersebut dapat diubah menjadi tidak dijelaskan secara lebih rinci, sehingga akan selaras dengan kata-kata sebelum maupun sesudahnya.

\section{Kesalahan Penulisan Paragraf}

Penulisan paragraf yang baik umumnya ditandai dengan adanya kalimat utama dan diikuti dengan beberapa kalimat penjelas. Suatu paragraf juga ditandai dengan beberapa syarat, yaitu kesatuan, kepaduan, dan kesinambungan kalimat satu dengan kalimat yang lain. Berikut merupakan data penemuan kesalahan paragraf pada teks ulasan buku fiksi siswa kelas XI SMA Muhammadiyah 1 Karanganyar.

(18) Novel ini bercerita mengenai 5 orang pemuda dan pemudi yang menjalani persahabatan dan memiliki kepribadian yang berbeda. Tokoh-tokoh dalam novel ini yang pertama adalah Riani, sosok gadis cantik yang tinggi ingin menjadi seorang presenter di salah satu stasiun TV.

Tokoh selanjutnya adalah Zafran, gayanya sangat menampakkan bahwa dirinya adalah anak band, berbadan kurus, dan sosok Zafran ini selalu menjadi pelebur suasana dalam kisah sahabat dalam novel $5 \mathrm{~cm}$. kemudian adalah sosok Arial yang memiliki badan sporty dan selalu tampak rapi dalam acara apapun. (1/1-2)

Data diatas merupakan penulisan paragraf yang kurang tepat. Tulisan pada paragraf kedua merupakan lanjutan dari paragraf pertama, sehingga dapat dikatakan bahwa paragraf kedua adalah penjelas dari paragraf pertama. Maka dari itu, penulisan paragraf yang benar 
seharusnya antara paragraf satu dan paragraf dua digabung menjadi satu paragraf yang utuh.

\section{SIMPULAN}

Berdasarkan hasil analisis temuan kesalahan dan pembahasan mengenai data penelitian, kesalahan struktur wacana dan kesalahan berbahasa Indonesia pada teks ulasan buku fiksi siswa kelas XI SMA Muhammadiyah 1 Karanganyar dapat disimpulkan sebagai berikut.

Bentuk dan jenis kesalahan stuktur teks ulasan buku fiksi siswa SMA Muhammadiyah 1 Karanganyar dianalisis ke dalam beberapa aspek, yaitu analisis pada aspek judul teks ulasan, identitas buku, pendahuluan atau orientasi, tafsiran isi, dan penutup teks ulasan. Kesalahan paling banyak terdapat pada penulisan judul ulasan yaitu terdapat 20 kesalahan dari 21 data yang dianalisis. Ditemukan 17 kesalahan pada bagian penutup, 12 kesalahan pada bagian tafsiran isi, dan 11 kesalahan pada bagian pendahuluan atau orientasi.

Bentuk dan jenis analisis kesalahan berbahasa Indonesia pada teks ulasan buku fiksi siswa kelas XI SMA Muhammadiyah 1 Karanganyar dianalisis ke dalam beberapa aspek, yaitu analisis pada aspek ejaan dan tanda baca, diksi, kalimat, dan paragraf. Pada penelitian ini, kesalahan paling banyak terdapat pada aspek ejaan dan tanda baca, yaitu pada penulisan huruf besar terdapat 174 kesalahan. Terdapat 60 kesalahan penulisan tanda baca koma, 36 kesalahan tanda baca titik, 18 kesalahan kata depan, 10 kesalahan huruf miring, 4 kesalahan titik dua, 3 kesalahan tanda hubung, 3 kesalahan kata ulang, 3 kesalahan partikel, dan 2 kesalahan penulisan titik koma. Kesalahan diksi yang ditemukan, yaitu 33 kesalahan ketidaktepatan pemilihan kata, 28 kesalahan ketidakhematan kata, 22 kesalahan kata baku, dan 12 kesalahan ketidaklaziman kata. Selain itu, terdapat pula kesalahan kalimat dan kesalahan paragraf pada penelitian ini.

Faktor penyebab kesalahan struktur teks ulasan dan kesalahan berbahasa Indonesia pada teks ulasan buku fiksi siswa kelas XI di SMA Muhammadiyah 1 Karanganyar disebabkan oleh beberapa faktor, yaitu (1) pembahasan mengenai ejaan dan tanda baca tidak ada pada materi pembelajaran di kurikulum 2013, (2) kurangnya motivasi siswa dalam membaca dan menulis mempengaruhi banyak sedikitnya kesalahan struktur maupun kesalahan berbahasa siswa, (3) adanya pengaruh bahasa asing dan bahasa daerah.

Upaya yang dilakukan untuk meminimalkan kesalahan struktur maupun kesalahan berbahasa dalam penulisan teks ulasan oleh siswa kelas XI SMA Muhammadiyah 1 Karanganyar, antara lain (1) dengan melakukan pengintegrasian materi ejaan dan tanda baca dengan materi teks ulasan, (2) guru memberikan motivasi kepada siswa untuk gemar membaca dan menulis, dan (3) peningkatan penguasaan kaidah kebahasaan yang benar dengan cara guru memberikan contoh berbahasa yang benar ketika pembelajaran di sekolah.

\section{REFERENSI}

Akhadiah, S., Arsjad, M.G., \& Ridwan, S.H. (1993). Pembinaan Kemampuan Menulis Bahasa Indonesia. Jakarta: Penerbit Erlangga.

Ariningsih, N. E., Sumarwati, \& Saddhono (2012). Analisis Kesalahan Berbahasa Indonesia dalam
Karangan Eksposisi Siswa Sekolah Menengah Atas. Jurnal Basastra. 1 (1). 1-12.

Eriyanto. (2015). Analisis Isi: Pengantar Metodologi untuk Penelitian Ilmu Komunikasi dan Ilmu-ilmu Sosial Lainnya. Jakarta: Prenada Media. 
Gordon, L. (2008). Writing and Good Language Learner. In C. Griffiths (Ed), Lesson from Good Language Learners. Cambriedge: Cambriedge University Press.

Media Indonesia. (2001). Kemampuan Menulis Orang Indonesia Lemah. http://perpustakaan.bappenas.go.id/1 ontar/file?file=digital/blob/F10067/ Kemampuan\%20Menulis\%20Orang \%20Indonesia\%20Lemah.htm.

Diakses 25 Februari 2019.

Moleong, L.J. (2007). Metodologi Penelitian Kualitatif. Bandung: Remaja Rosdakarya.

Nasution, S. 1988. Metode Penelitian Naturalistik Kualitatif. Bandung: Tarsito.

Novitasari, E., Mustofa, A., \& Karomani. (2015). Kemampuan Menulis Teks Ulasan/Resensi Siswa Kelas VIII SMP Negeri 2 Kotagajah. Jurnal Kata (Bahasa, Sastra, dan Pembelajarannya). 3 (3), 1-12.

Siregar, N.Y. \& Rosmaini. (2018). Kemampuan Mengidentifikasi Struktur dan Unsur Kebahasaan oleh Siswa Kelas VIII SMP Negeri 12 Medan Tahun Pelajaran 2017/2018. Jurnal Basastra. 7 (2), 128-136.

Sukardi \& Sutarni, S. (2008). Bahasa Indonesia 3 SMA Kelas XII. Jakarta: Penerbit Quadra.

Wahya \& Waridah, E. (2017). Buku Besar Bahasa Indonesia: untuk SD/SMP/SMA. Jakarta: Penerbit Bmedia. 